\title{
ON THE THYROID MORPHOLOGY AND THE LEVEL OF MILK YIELD AMONG THE PROGENY OF GOITROUS AND APPARENTLY NORMAL COWS
}

\author{
VAPPU Kossila \\ Department of Animal Husbandry, University of Helsinki
}

Received July 6, 1969

Thyroid activity as well as disposition to a goitrous condition are obviously influenced to a certain degree by hereditary factors.

Individual variations have been observed in the activity and weight of the thyroid in the same breed of dairy cows. The thyroxine secretion rate (TSR) (Hamblin et al. 1958, Premachandra et al. 1958b) and the level of protein bound iodine (PBI) in serum (Kossila 1963) were found to vary considerably in individual cows during the same season. In the same herd, a number of cows had enlarged thyroids while others had thyroids normal by weight even though all of them had been given the same kind of feeds (Kossila 1967). According to Schultz (1962), goiter in cattle might be due to a recessive gene and the condition is not linked with sex.

Significant daughter-dam correlations in respect of the PBI level in winter $(r=0.59)$, and seasonal differences in the PBI level $(\mathrm{r}=0.73)$, have been noted by Окамото et al. (1963) in cattle. Premachandra et al. (1958a) observed a significant difference in the TSR in two lines of New Hampshire fowls, selected for three generations on the basis of their response to feeding thiouracil by variation in the average thyroid weight. The line with a high thyroid enlargement had TSR $1.02 \mu \mathrm{g} / 100 \mathrm{~g}$ body weight L-thyroxine, and the line with the low thyroid enlargement had TSR $2.98 \mu \mathrm{g}$ respectively. At present there is fairly little direct evidence to demonstrate the extent to which endocrine characteristics pass from dam to daughter in cows. However, according to Turner (1968b) a faster improvement in dairy cattle would be achieved if the breeding animals (especially the bulls) were selected on the basis of their hormonal secretion rates, for instance, on the basis of their TSR. Since the most convenient and reliable methods applied to the estimation of the TSR require the use of $\mathrm{I}^{131}$, and the health regulations today prohibit the utilization of meat from animals treated with this isotope, large scale TSR studies in cattle meet with particular difficulties. The in vitro uptake by erythrocytes of the $\mathrm{I}^{131}$-L-triiodo- 
thyronine is probably not sensitive enough for this purpose, neither is the PBI level in serum. Since the weight and histological characteristics of the thyroid can be estimated sufficiently accurately only after the death of the animals, they are not very suitable for this reason. Besides, the thyroid structure depends largely on certain nutritional factors, and the structural changes occurring in it are not necessarily associated with corresponding changes in the TSR.

An attempt has nevertheless been made in this study to ascertain the extent to which the weight and the epithelial tissue content of the thyroid of so-called normal, slightly goitrous, and goitrous dam-cows are manifested in their daughters. Attention has been paid also to the milk yield of the cows, since the thyroid is one of the endocrine glands, whose function is important in maintaining the milk yield at an optimal level (TURNER 1968a).

\section{Material and methods}

The thyroids were obtained from cows discarded from the Ayrshire herd of the Viik Experimental Farm during the years 1958 - 66. The feeding and management of this herd has been recently described in detail (KossiLA 1967, pp. 32-36).

The percentage of epithelial tissue $(\mathrm{E} \%)$ in the thyroid specimens was estimated histoquantitatively by the method of Uotila \& Kannas (1952). The accuracy of this method has been discussed by Tala (1952). The absolute amount of epithelial tissue contained per thyroid gland in grams $(\mathrm{Eg})$ was calculated on the basis of $\mathrm{E} \%$ and the wet weight of the gland. The Eg is not influenced by the age of the cow, but it is slightly affected by the body size (KossiLA 1969b). Furthermore, especially in growing $(<60$ months old) cows, the Eg seems to be a better indicator of goiter than the thyroid weight (Kossila 1967).

The body weight, corrected for the stage of gestation and/or for the degree of fatness, was used in this study as an indicator of the body size of the cows, because it was previously noted that the weight (Kossila 1967, p. 73) and the Eg (Kossila 1969b) of the thyroid gland, as well as the milk yield (writer's observation), were more closely correlated with the corrected body weight than with the live weight of the cows at slaughter. The method used in estimating the corrected body weight has been explained previously in greater detail (KossiLa 1967, p. 37-39). The relative thyroid weight (BRT = bovine relative thyroid weight) was obtained by calculating the thyroid weight in grams per $100 \mathrm{~kg}$ corrected body weight. The mean daily fat corrected milk (FCM) yield in kg during the productional life time of the cow was used as an indicator of the lactational performance. The age of the cow was also noted, since it is known to affect, among others, the thyroid weight.

The data, consisting altogether of 51 dams, of which 26 had one daughter, 19 two daughters, 4 three daughters, and 2 four daughters, i.e. altogether 84 daughters (heiferdaughters were omitted from this study), was first divided into three groups according to the thyroid weight of the dam (Table 1). Group I consisted of 29 dams whose thyroids weighed less than $30 \mathrm{~g}$ (apparently normal), group II included 17 dams whose thyroids ranged from 30 to $50 \mathrm{~g}$ (slightly goitrous), and group III 5 dams with thyroids heavier than $50 \mathrm{~g}$ (goitrous). 
Table 1. The mean values and standard deviations of the thyroid weight, the BRT, the Eg, the corrected body weight, age, and the FCM yield of three groups (apparently normal I, slightly goitrous II, goitrous III) of dams and in the corresponding groups of their daughters.

\begin{tabular}{|c|c|c|c|c|c|c|c|}
\hline Group & $\mathrm{N}$ & $\begin{array}{c}\text { Thyroid } \\
\text { weight, } g\end{array}$ & $\left.\mathrm{BRT}^{\mathbf{1}}\right)$ & $\left.\mathrm{Eg}^{2}\right)$ & $\begin{array}{l}\text { Corrected } \\
\text { body } \\
\text { weight, } \mathrm{kg}\end{array}$ & $\begin{array}{l}\text { Age, } \\
\text { months }\end{array}$ & $\begin{array}{c}\mathrm{FCM}^{3} \text { ) } \\
\text { yield, } \mathrm{kg}\end{array}$ \\
\hline \multicolumn{8}{|l|}{$\mathrm{Da} \mathrm{m} \mathrm{s}$} \\
\hline I & 29 & $24.17 \pm 3.14$ & $4.55 \pm 0.55$ & $4.81 \pm 1.46$ & $497 \pm 41$ & $85.6 \pm 21.8$ & $14.64 \pm 1.36$ \\
\hline II & 17 & $38.13 \pm 5.82$ & $7.42 \pm 1.78$ & $5.37 \pm 1.68$ & $507 \pm 47$ & $107.7 \pm 35.4$ & $13.93 \pm 1.97$ \\
\hline III & 5 & $61.22 \pm 5.06$ & $11.46 \pm 1.48$ & $6.96 \pm 4.88$ & $517 \pm 37$ & $119.2 \pm 35.0$ & $13.48 \pm 1.18$ \\
\hline$I I+I I I$ & 22 & $43.38 \pm 11.35$ & $8.34 \pm 2.41$ & $5.73 \pm 2.68$ & $510 \pm 45$ & $110.3 \pm 34.8$ & $13.83 \pm 1.80$ \\
\hline $\mathrm{I}+\mathrm{II}+\mathrm{III}$ & 51 & $32.46 \pm 12.32$ & $6.19 \pm 2.49$ & $5.21 \pm 2.10$ & $502 \pm 43$ & $96.2 \pm 31.5$ & $14.29 \pm 1.65$ \\
\hline \multicolumn{8}{|l|}{ Daughers } \\
\hline I & 42 & $21.07 \pm 5.10$ & $4.18 \pm 1.00$ & $4.13 \pm 1.06$ & $474 \pm 49$ & $61.8 \pm 24.6$ & $15.06 \pm 2.38$ \\
\hline II & 32 & $24.51 \pm 7.90$ & $4.92 \pm 1.26$ & $4.81 \pm 1.59$ & $462 \pm 53$ & $59.8 \pm 24.3$ & $13.78 \pm 1.98$ \\
\hline III & 10 & $31.58 \pm 10.21$ & $6.29 \pm 2.55$ & $5.61 \pm 1.83$ & $489 \pm 54$ & $64.0 \pm 26.9$ & $13.94 \pm 1.95$ \\
\hline $\mathrm{II}+\mathrm{III}$ & 42 & $26.20 \pm 8.90$ & $5.25 \pm 1.73$ & $5.00 \pm 1.66$ & $469 \pm 54$ & $60.8 \pm 24.7$ & $13.81 \pm 1.95$ \\
\hline $\mathbf{I}+\mathrm{II}+\mathrm{III}$ & 84 & $23.63 \pm 7.66$ & $4.71 \pm 1.50$ & $4.57 \pm 1.44$ & $471 \pm 51$ & $61.3 \pm 24.5$ & $14.42 \pm 2.21$ \\
\hline
\end{tabular}

$\mathrm{N}=$ Number of cases.

${ }^{1}{ }^{2}{ }^{3}$ ) Abbreviations explained in the text.

Histologically the goitrous thyroids resembled struma hypoepithelialis, medio- \& macrofollicularis (ref. Uotila 1957) i.e. colloid goiter. This type is apparently less severe than the struma hyperepithelialis micro- \& mediofollicularis (parenchymatous goiter).

Statistical calculations were done according to Croxton \& Cowden (1955).

\section{Results and discussions}

The following values, the thyroid weight in $\mathrm{g}\left(\overline{\mathrm{x}}_{1}\right)$, the BRT-value $\left(\overline{\mathrm{x}}_{1 \mathrm{~A}}\right)$, the Egvalue $\left(\overline{\mathrm{x}}_{1 \mathrm{~B}}\right)$, the corrected body weight in $\mathrm{kg}\left(\overline{\mathrm{x}}_{2 \mathrm{~A}}\right)$, the age in months $\left(\overline{\mathbf{x}}_{3}\right)$, and the FCM yield in $\mathrm{kg}\left(\overline{\mathrm{x}}_{4}\right)$ obtained for the dams in groups I, II and III, and correspondingly for their daughters, are presented in Table 1. Also the results obtained after combining groups II + III and all three groups, are given in Table 1. The dam-daughter correlations obtained for the said factors have been summarized in Table 2.

Thyroid characteristics. Results in Table 1 indicate clearly that the characteristics of the thyroids of the daughter-cows exhibited trends similar to those of their dams. The dams as well as the daughters in group I had the lowest thyroid weights and BRT- and Eg-values, and those in group III the highest values, correspondingly. However, as a whole, the dams had considerably higher thyroid weights and BRT- and Eg-values than their daughters.

There are a number of factors largely or entirely independent from those inherited from the dam (effect of sire, nutritional conditions prevailing during the intrauterine 
Table 2. The dam-daughter correlations in respect of the thyroid characteristics, body size, age, and FCM-yield of the cows.

\begin{tabular}{llllllll}
\hline Group & N & $\begin{array}{c}\text { Thyroid } \\
\text { weight }\end{array}$ & BRT & Eg & $\begin{array}{c}\text { Corrected } \\
\text { body } \\
\text { weight }\end{array}$ & Age & $\begin{array}{c}\text { FCM } \\
\text { yield }\end{array}$ \\
\hline I & 42 & 0.13 & 0.07 & 0.27 & 0.22 & 0.25 & $0.42 * *$ \\
II + III & 42 & $0.40^{* *}$ & $0.41^{* *}$ & 0.24 & 0.07 & 0.15 & 0.22 \\
I + II + III & 84 & $0.47 * * *$ & $0.49 * * *$ & $0.30 * *$ & 0.13 & 0.16 & $0.35 * * *$ \\
\hline
\end{tabular}

$\mathrm{N}=$ number of dam-daughter pairs

$* * *=\mathrm{P}<0.001$

$* *=\mathrm{P}<0.01$

growth and development as well as later in life, the environmental climate, season of birth, diseases, age at death, etc.) that may cause variations in the characteristics of the thyroid in the offspring. Some of these factors have been considered in this paper.

Goiter was found in a number of animals slaughtered before the year 1960 from the Viik dairy herd. This condition was believed to be primarily due to the marginal or low iodine content of the ration (Kossila 1967, p. 89, 98). In these conditions several damdaughter pairs developed goiter while others remained apparently normal. Some examples of this are given below.

D a m

Da ug ter

\begin{tabular}{|c|c|c|c|c|c|c|c|}
\hline Name & $\begin{array}{c}\text { Thyroid } \\
\text { weight, g }\end{array}$ & BRT & $\begin{array}{l}\text { Age in } \\
\text { months }\end{array}$ & Name & $\begin{array}{c}\text { Thyroid } \\
\text { weight, g }\end{array}$ & BRT & $\begin{array}{l}\text { Age in } \\
\text { months }\end{array}$ \\
\hline \multirow[t]{2}{*}{ Joiku } & 62.20 & 12.30 & 125 & ${ }^{*}$ Oikku & 41.00 & 9.21 & 45 \\
\hline & & & & Pikku & 52.50 & 11.41 & 41 \\
\hline \multirow[t]{2}{*}{ Juhla } & 33.70 & 5.03 & 122 & Mallu & 26.70 & 4.62 & 70 \\
\hline & & & & Ohra & 25.00 & 5.30 & 43 \\
\hline \multirow[t]{2}{*}{ Maissi } & 20.50 & 3.88 & 108 & Paija & 16.60 & 3.61 & 50 \\
\hline & & & & Eini & 14.47 & 3.63 & 44 \\
\hline
\end{tabular}

* cow treated with KI by mouth three weeks prior to slaughter.

The results in the above compilation indicate clearly that the thyroid weights and BRTvalues of the daughters resembled those of their dams; the somewhat lower thyroid weights in the daughters were apparently due to their ages being lower.

Furthermore, when supplemental iodine, in a form of iodized mineral salt mixture, was given to the dam during the entire period of gestation, the weight of the thyroid in the offspring (daughter) tended to become smaller. This phenomenon is demonstrated in the examples given below. 


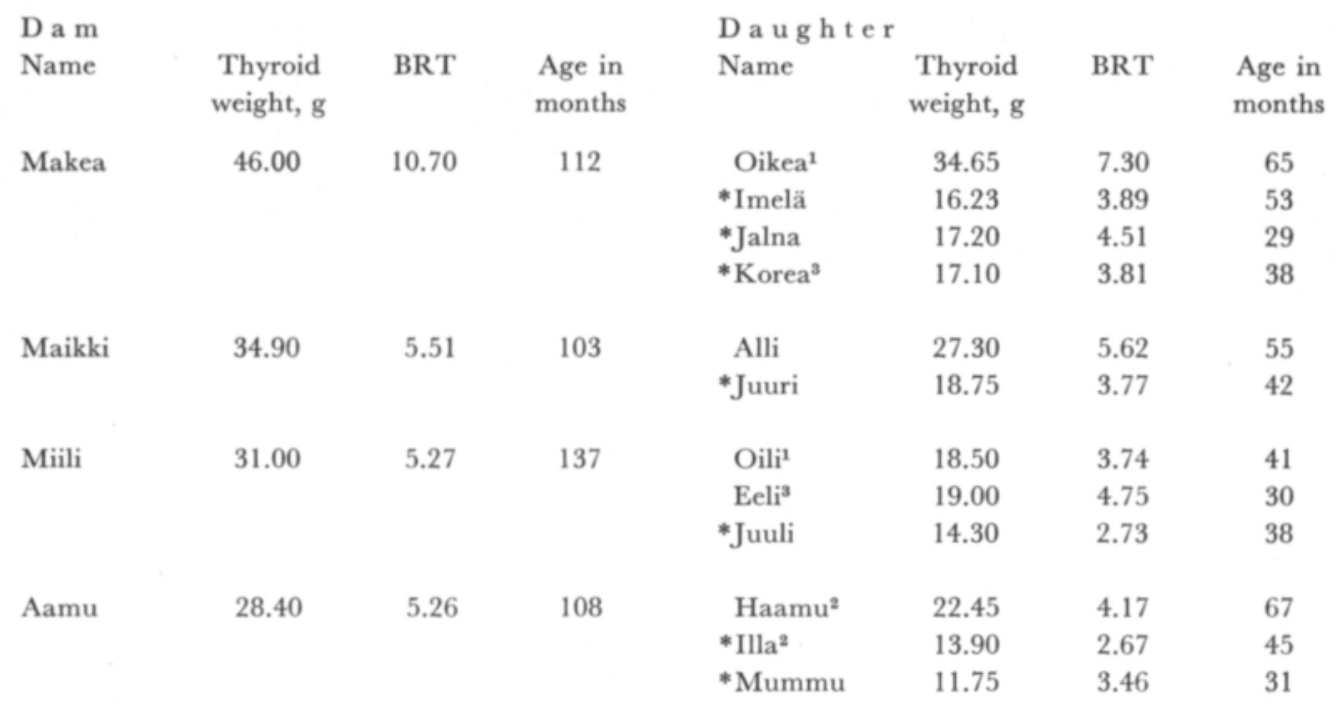

* the dam received supplemental iodine during the period of gestation from which the daughter was born.

${ }^{1}$ sire R-Jaarli ${ }^{2}$ sire V. Aito ${ }^{3}$ sire L. Nerokas

The differences in age of the daughters of the same dam in the above compilation are not large enough to account for the differences noted in their thyroid weights. Moreover, if the diet contains apparently enough iodine but hardly any goitrogenic substances, the effect of age on the weight of the thyroid becomes less evident in cows (Kossila 1969a).

B o dy weig ht, a g e, a n d milk y i e ld. In the present data the body weight and age of the dams were higher than those of the daughters, whereas the FCM yield was nearly the same in both (Table 1).

The body weight and age of the dams were the lowest in group I and the highest in group III, whereas those of the daughters were the lowest in group II and the highest in group III. The FCM yield of the dams and the daughters was highest in group I, whereas the FCM yield of the dams was lowest in group III, but that of the daughters lowest in group II.

It was previously noted in the same herd (writer's observation) that the FCM yield was positively correlated with the corrected body weight of the cows. In order to eliminate the effects on milk yield of the variations in the body weight, the FCM yield was computed to correspond to $500 \mathrm{~kg}$ corrected body weight. The results thus obtained for all groups of dams and, respectively, for the daughters are summarized in the following compilation.

\begin{tabular}{lcccc} 
Group & \multicolumn{2}{c}{$\begin{array}{c}\text { Mean daily FCM yield in } \\
\text { kg/500 kg corrected body wt. } \\
\text { Dams }\end{array}$} & $\begin{array}{c}\text { Daughters } \\
\text { Dame difference in favor of } \\
\text { the daughters } \\
\text { kg }\end{array}$ & $\begin{array}{c}\text { The } \\
\text { I }\end{array}$ \\
II & 14.73 & 15.87 & +1.14 & 7.74 \\
III & 13.74 & 14.92 & +1.18 & 8.59 \\
II + III & 13.04 & 14.28 & +1.25 & 9.59 \\
I + II + III & 13.56 & 14.73 & +1.17 & 8.63 \\
\end{tabular}


According to the above results, the FCM yield per $500 \mathrm{~kg}$ body weight has decreased uniformly from group I to III in the dams (by $1.69 \mathrm{~kg}$ ) as well as in the daughters (by $1.59 \mathrm{~kg}$ ) the milk yield being consistently higher in the latter. The difference in the FCM yield in favor of the daughters would obviously have been even larger than indicated by the above figures, if the daughters had been as old as their dams, because the level of milk production in the said herd has tended to increase up to the 5 th -6 th calving, i.e. up to the age of 85-95 months (Kossila \& TAskinen 1969), and the mean age of all daughter cows was only 61.3 months (Table 1).

In addition to the possible effect of the sire, the higher FCM yield of the daughters may also have been due to a more efficient thyroid function resulting from the normalization of the thyroid gland (ref. Kossila 1969a).

Thyroid characteristics versus milk yield. The weight of the thyroid and the Eg- and the BRT-values were the lowest, and the FCM yield per $500 \mathrm{~kg}$ corrected body weight was the highest in the daughters of group I, whereas the reverse was true in the dams of group III (Table 1). In fact, the larger the thyroid weight, the Eg-, and the BRT-values, the lower the FCM yield per $500 \mathrm{~kg}$ corrected body weight. A significant negative correlation between the Eg value and the FCM yield was noted earlier in more heterogenous cow material of the same herd, but only, when goitrous individuals were included in the data (KossiLA 1969b); the thyroid weight, in turn, was not significantly related to the respective FCM yield (Kossila 1967, p. 73).

$\mathrm{D}$ a m - d a u g h t e r c or relat i o n s. The dam-daughter correlations, calculated in respect of the thyroid weight, the Eg, the BRT, the corrected body weight, the FCM yield, and age at slaughter, have been summarized in Table 2. The coefficients of the correlations were obtained separately for group I, for groups II + III, and for the entire material, i.e. for groups I + II + III, but not for the groups II or III the data being too limited.

The dam-daughter correlations in respect of the thyroid weight and the BRT (the effect of body size on the thyroid weight eliminated in BRT) were non-significant in group $\mathrm{I}(\mathrm{r}=0.13, \mathrm{r}=0.07$ respectively) but significant in groups II + III $(\mathrm{r}=0.40 * * *$, $\left.\mathrm{r}=0.41^{* *}\right)$ and in the entire material $\left(\mathrm{r}=0.47^{* * *}, \mathrm{r}=0.49^{* * *}\right)$. The dam-daughter correlation in respect of the $\mathrm{Eg}$ was significant only in the entire material $\left(\mathrm{r}=0.30^{* *}\right)$. When the effect of body weight on the $\mathrm{Eg}$ value was eliminated by means of calculating the Eg as corresponding to $500 \mathrm{~kg}$ corrected body weight, the dam-daughter correlation, $\mathrm{r}=0.31^{* *}$, obtained for the entire material was only slightly closer compared to the previously presented respective correlation, in which the body weight has not been taken into consideration. It seems that the dam-daughter correlations in respect of the thyroid weight and the Eg value were not appreciably influenced by the body weight of the cows.

According to earlier observations (KossiLA 1967, p. 76-79, 88 - 89), even in conditions in which the iodine intake was apparently marginal or low, the Eg value was not appreciably influenced by the age of the cow. The thyroid weight and the BRT value, on the other hand, increased significantly with age in full-grown but not in growing cows $(<60$ months old). Furthermore, in the latter the Eg value was superior in revealing the tendency towards goiter when compared to the thyroid weight. The BRT-value of the dams in the present data was significantly correlated with age in group $\mathrm{I}\left(\mathrm{r}=0.41^{* *}\right)$, in groups II + III $\left(\mathrm{r}=0.38^{* *}\right)$, and in groups I + II + III $\left(\mathrm{r}=0.48^{* * *}\right)$, whereas the BRT 
value of the daughters was not significantly influenced by age $(\mathrm{r}=0.18, \mathrm{r}=0.03$, and $\mathrm{r}=0.24)$. It seems quite possible that the dam-daughter correlations obtained in respect of the thyroid weight and the BRT-value (Table 2) are somewhat influenced by age, whereas those obtained in respect of the Eg are not.

The dam-daughter correlations in respect of the corrected body weight and age of cows were closer in group I $(r=0.22$ and $r=0.25)$ than in groups II + III $(r=0.07$, $\mathrm{r}=0.15)$, or in the entire material $(\mathrm{r}=0.13, \mathrm{r}=0.16)$ (Table 2), but nevertheless nonsignificant, suggesting that probably neither the body weight nor age had played a marked role in dam-daughter correlations concerning thyroid characteristics.

The dam-daughter correlations in respect of the FCM yield were significant in group I $\left(r=0.42^{* *}\right)$ and in the entire material $\left(r=0.35^{* *}\right)$ but non-significant in groups II + III $(r=0.22)$ (Table 2$)$, i.e. in groups consisting of slightly goitrous and goitrous dams (Table 1).

\section{Conclusions}

The results of this study indicate that the tendency towards goiter was transferred from the dam to the daughter and that in favorable nutritional conditions (after addition of supplemental iodine) this tendency diminished suggesting that severe inherited enzyme defects were apparently not involved. It would rather seem that the goitrous individuals had been less efficient in maintaining a positive iodine balance during certain phases of their life than the nongoitrous ones.

The FCM yield of cows in the present data was in inverse relation to the thyroid weight, the $\mathrm{Eg}$, as well as the BRT values.

\section{Sum mary}

The thyroid morphology and the level FCM yield were studied in 84 dam-daughter pairs discarded from the Ayrshire herd of the Viik Experimental Farm. Data was divided into three groups according to the thyroid weight of the dam: less than $30 \mathrm{~g}$ in group $\mathrm{I}$, from 30 to $50 \mathrm{~g}$ in group II, and $50 \mathrm{~g}$ or over in group III.

The following mean values were obtained for the dams and their daughters: thyroid weight in grams: I 24.17 and 21.07 , II 38.13 and 24.51 , III 61.22 and 31.58 ; thyroid weight in grams per $100 \mathrm{~kg}$ corrected body weight (BRT): I 4.55 and 4.18, II 7.42 and 4.92, III 11.46 and 6.29; absolute amount of epithelial tissue contained per thyroid in grams (Eg): I 4.81 and 4.13, II 5.37 and 4.81, III 6.96 and 5.61; corrected body weight in $\mathrm{kg}$ : I 497 and 474, II 507 and 462, III 517 and 489; age in months: I 85.6 and 61.8, II 107.7 and 59.8, III 119,2 and 64.0; mean FCM yield in $\mathrm{kg}$ during productional lifetime: I 14.64 and 15.06, II 13.93 and 13.78, III 13.48 and 13.94; FCM yield in kg per $500 \mathrm{~kg}$ corrected body weight: I 14.73 and 15.87, II 13.74 and 14.92 , III 13.04 and 14.28 .

The lower thyroid weight in daughters was apparently due to their lower body weight and age as well as to the higher iodine content of the ration.

The dam-daughter correlations in respect of the thyroid weight, the BRT, the Eg, the corrected body weight, age, and FCM-yield were: I $0.13,0.07,0.27,0.22,0.25$, and 
$0.42^{* *}$, II + III $0.40^{* *}, 0.41^{* *}, 0.24,0.07,0.15$, and 0.22, I + II + III $0.47 * * *$, $0.49 * * *, 0.30 * *, 0.13,0.16$, and $0.35 * * *$.

The results of this study indicate a) that the incidence of goiter was higher in the progeny of goitrous than in that of normal dams, b) that the incidence of goiter in the daughters decreased if the goitrous dam received supplemental iodine during the gestation period from which the daughter was born, c) that a heavier thyroid weight resulted in a lower FCM yield.

Acknowledgements. This study has been subsidized by a grant from the August and Aino Tiura's Foundation.

\section{REFERENCES}

Croxton, F. E. \& Cowden, D. J. 1955. Applied general statistics. 2nd ed. Pitman, London. XVI + 843 pp. Chapt 21.

Hamblin, F. B., Johnston, J. E. \& Schrader, G. 1958. PBI and $\mathrm{I}^{131}$ extrapolation technique as methods of determining thyroid activity in dairy cows. J. Dairy Sci. 41: 728.

Kossit. , V. 1963. Effects of season and stage of lactation on protein bound iodine and total cholesterol in serum of dairy cows. J. Sci. Agr. Soc. Finland 35: 81-91.

- - 1967. On the weight and basic structural components of the thyroid in dairy cattle. Acta Agr. Fennica 109.2.

- - 1969a. On the development of the thyroid weight in the dairy herd of the Viik Experimental Farm. J. Sci. Agr. Soc. Finland 41: 149-153.

-n- 1969b. Simple and partial correlations between the epithelial tissue content of the thyroid, the body weight, age, and level of milk yield in Ayrshire cows. Ibid. 41: 154-159.

—- \& TAskinen, P. 1969. Sources of variation in the birth weight of Ayrshire calves. Ibid. $41: 180-190$.

Окамото, S., Goto, I. \& KogA, O. 1963. Statistical studies on the inheritance of heat tolerance in dairy cows. Sci. Bull. Fac. Agric. Kyushu Univ. 20: 211-215. (ref. Anim. Breed. Abstr. 32: 473, 1964).

Premachandra, B. N., Pipes, W. G. \& Turner, C. W. 1958a. Thyroxine secretion rates of two strains of New Hampshire chickens selected for high and low response to thiouracil. Poultry Sci. 37: 399. -\#- - - - - - 1958b. Variation in the thyroxine secretion rate of cattle. J. Dairy Sci. 41: 1609.

Schulz, K. C. A. 1962. The inheritance of the suspectibility of gongenital goitre in Africander cattle in South Africa. Proc. 2nd Congr. S. Afr. genet. Soc. 90-93.

TALA, P. 1952. Histoquantitative studies on the effect of TSH and thyroxin on the morphology of the thyroid gland, with special reference to standardisation of TSH. Diss. Helsinki. Acta Endocrin. X, Suppl. 9.

Turner, C. W. 1968a. What causes high production? Story of the role of the thyroid glands in milk secretion. Mo. Agr. Exp. State Bull. 871.

-n- 1968b. (Personal communication) Department of Dairy Husbandry, University of Missouri, Columbia Mo. U.S.A.

UotilA, U. 1957. Thyreoideas histofysiologi. Nord. Med. 57: 809.

— - \& Kannas, O. 1952. Quantitative histological method of determining the proportions of the principal components of the thyroid tissue. Acta Endocrin. 11: 49-60. 


\title{
SELOSTUS
}

\section{EMÄ-TYTÄR TUTKIMUS KILPIRAUHASEN MORFOLOGISISTA PIIRTEISTÄ JA MAITOTUOTOSTASOSTA VIIKIN AYRSHIRE KARJASSA}

\author{
VAPPU Kossila \\ Helsingin yliopiston kotieläintieteen laitos
}

Tutkimusaineisto käsitti 84 vuosina 1958 - 66 Viikin Ayrshire karjasta poistettua emä-tytär paria. Tutkimuksessa tarkasteltiin erityisesti kilpirauhasen morfologisia ominaisuuksia sekä maitotuotosta. Aineisto jaettiin kolmeen ryhmään emien kilpirauhaspainon mukaan seuraavasti: $\mathrm{I}$ alle $30 \mathrm{~g}$ normaali, II $30-50 \mathrm{~g}$ lievä struuma ja III yli $50 \mathrm{~g}$ selvä struuma.

Seuraavat keskiarvot (Taulukko 1) saatiin emille ja tyttärille vastaavasti: kilpirauhasen paino g: I 24.17 ja 21.07 , II 38.13 ja 24.51 , III 61.22 ja 31.58 ; kilpirauhasen paino grammoina $100 \mathrm{~kg}$ tiineys ja/tai lihavuuskunto korjattua elopainoa kohden: I 4.55 ja 4.18, II 7.42 ja 4.92, III 11.46 ja 6.29 ; epiteelisolukon määrä grammoina per kilpirauhanen: I 4.81 ja 4.13 , II 5.37 ja 4.81 , III 6.96 ja 5.61 ; korjattu elopaino kg: I 427 ja 474 , II 507 ja 462, III 517 ja 489; ikä kuukausina: I 85.6 ja 61.8 , II 107.7 ja 59.8 , III 119.2 ja 64.0 ; keskim. päivässä tuotannollisina elinaikana tuotettu $4 \%$ :ksi muunnettu maitomäärä kg:na: I 14.64 ja 15.06 , II 13.93 ja 13.78 , III 13.48 ja 13.94 ; vastaava maitotuotos kiloina 500 kg korjattua elopainoa kohden: I 14.73 ja 15.87 , II 13.74 ja 14.92 , III 13.04 ja 14.28.

Tyttärien alhaisempi kilpirauhaspaino on johtunut osittain niiden pienemmästä ruumiin koosta ja alhaisemmasta iästä sekä myös runsaammasta jodimäärästä ravinnossa verrattuna emiin. Tyttärien korkeampi maitotuotos on saattanut johtua isän vaikutuksen ohella myös kilpirauhasen normalisoitumisesta.

Tutkimuksessa laskettiin emä-tytär vuorosuhde seuraavien tekijöiden välille: kilpirauhasen absoluuttinen ja suhteellinen paino, epiteelisolukon määrä grammoina per kilpirauhanen, korjattu elopaino, ikä ja maitotuotos (Taulukko 2), jotka koko aineistossa (I + II + III ryhmät) olivat vastaavasti seuraavat: $0.47 * * *, 0.49^{* * *}, 0.30^{* *}, 0.13,0.16$ ja $0.35 * * *$.

Tutkimuksessa kävi ilmi, että a) struumalehmien jälkeläisillä kilpirauhanen painoi enemmän kuin normaalilehmien jälkeläisillä, b) jälkeläisten kilpirauhaspaino laski kun jodipitoista rehusuolaseosta oli annettu struumalehmälle sen tiineyden aikana josta ko. jälkeläinen syntyi, c) mitä painavampi kilpirauhanen oli sen alhaisempi oli maitotuotostaso. 